\title{
Conflict ecologies: connecting political ecology and peace and conflict studies
}

\author{
Philippe Le Billon ${ }^{1}$ \\ Rosaleen Duffy \\ University of British Columbia, Canada \\ University of Sheffield, UK
}

\begin{abstract}
Conflict is at the core of many political ecology studies. Yet there has been limited engagement between political ecology and the field of peace and conflict studies. This lack of connection reflects in part the broader disciplinary context of these two fields. Whereas political ecology research mostly comes from disciplines that eschewed environmental determinism, such as human geography, much of peace and conflict studies is associated with political science using positivist approaches to determine the causal effects of environmental factors on conflicts. Yet greater connections are possible, notably in light of political ecology's renewed engagement with 'materialism', and peace and conflict studies' increasingly nuanced mixed-methods research on environment-related conflicts. Furthermore, political ecology's emphasis on uneven power relations and pursuit of environmental justice resonates with the structural violence approaches and social justice agenda of peace and conflict studies. This article provides an overview of the differing conceptualizations and analyses of environmental conflict under the labels of political ecology and peace and conflict studies, and points at opportunities for closer connections.
\end{abstract}

Keywords: conflict, violence, political ecology, peace and conflict studies

\section{Résumé}

Les conflits sont au cœur de nombreuses études d'écologie politique. Pourtant, il y a eu un engagement limité entre l'écologie politique et le domaine des études sur la paix et les conflits. Ce manque de connexion reflète en partie le contexte disciplinaire plus large de ces deux domaines. Alors que la recherche en écologie politique provient principalement de disciplines qui évitent le déterminisme environnemental, comme la géographie humaine, une grande partie des études sur la paix et les conflits est associée aux sciences politiques utilisant des approches positivistes pour déterminer les effets causaux des facteurs environnementaux sur les conflits. Pourtant, des liens plus étroits sont possibles, notamment à la lumière de l'engagement renouvelé de l'écologie politique dans le «matérialisme», et de l'utilisation de méthodes mixes et d'analyses plus nuancées par les études sur la paix et les conflits. De plus, l'accent mis par l'écologie politique sur les relations de pouvoir inégales et la poursuite de la justice environnementale résonne avec les concepts de violence structurelle et la pursuite de justice sociale par les études sur la paix et les conflits. Cet article donne un aperçu des différentes conceptions et analyses des conflits environnementaux dans les domaines de l'écologie politique et des études sur la paix et les conflits, et souligne les possibilités d'un plus grand rapprochement.

Mots-clés: conflit, violence, écologie politique, études de paix et de conflit

\footnotetext{
${ }^{1}$ Philippe Le Billon, Professor, Department of Geography and the Liu Institute for Global Issues, University of British Columbia, Canada. Email: philippe.lebillon "at" ubc.ca. Rosaleen Duffy, Professor, Department of Politics, University of Sheffield, UK. Email: r.v.duffy "at" sheffield.ac.uk. The authors would like to thank reviewers and comments received during the 2016 Political Ecology Network (POLLEN) conference, as well as funding from Canada's Social Sciences and Humanities Research Council and a European Research Council Advanced Investigator Grant 694995 (BIOSEC, Biodiversity and Security, Understanding Environmental Crime, Illegal Wildlife Trade and Threat Finance).
} 


\section{Resumen}

El conflicto es el núcleo de muchos estudios de ecología política. Sin embargo, ha habido un compromiso limitado entre la ecología política y el campo de la paz y los estudios de conflictos. Esta falta de conexión refleja en parte el contexto disciplinario más amplio de estos dos campos. Mientras que la investigación de ecología política proviene principalmente de disciplinas que evitaron el determinismo ambiental, como la geografía humana, gran parte de los estudios sobre paz y conflicto están asociados con la ciencia política utilizando enfoques positivistas para determinar los efectos causales de los factores ambientales en los conflictos. Sin embargo, es posible establecer mayores conexiones, sobre todo a la luz de la renovada participación de la ecología política con el "materialismo" y la investigación de métodos mixtos cada vez más matizada de estudios de paz y conflictos sobre conflictos relacionados con el medio ambiente. Además, el énfasis de la ecología política en las relaciones desiguales de poder y la búsqueda de la justicia ambiental resuena con los enfoques de violencia estructural y la agenda de justicia social de la paz y los estudios de conflicto. Este documento proporciona una visión general de las diferentes conceptualizaciones y análisis del conflicto ambiental bajo las etiquetas de ecología política y estudios de paz y conflicto, y apunta a oportunidades para conexiones más cercanas.

Palabras clave: conflicto, violencia, ecología política, paz y estudios de conflictos

\section{Introduction}

Understanding conflicts is a prime focus of political ecology, a research approach which specifically engages with the causes and consequences of uneven power relations over natural resources and the environment. Two thirds of political ecology studies use the term 'conflict' in their analyses, the second most frequent after 'power.' ${ }^{2}$ Several definitions of political ecology also emphasize the centrality of conflict to the field: Martinez-Alier (2003: 71) classically defines political ecology as "the study of ecological distribution conflicts", and Paul Robbins identifies "environmental conflict" as one of the five major areas of political ecology, along with degradation and marginalization; conservation and control; environmental identity; and social movements; most of which also include conflictual dimensions (2004: 14). Yet, political ecology has hardly theorized conflict explicitly, in contrast with peace and conflict studies - another field that has engaged with conflicts related to natural resources and the environment.

Political ecology has its roots in human geography (especially critical development geography) and human ecology (especially cultural ecology), and so it is arguably well-equipped to study the potential connections between conflicts and environmental change. Yet, political ecologists seem to be much less willing than researchers in peace and conflict studies to assign powers of causation to environmental change, pointing instead to the risks of environmental determinism (Peluso and Watts 2001); and more generally being criticized internally for having pursued analysis of "politics without ecology" (Bassett and Zimmerer 2004: 103; Walker 2005). This habitual aversion to bringing the biophysical environment into the underlying causal web of conflict stems, in part, from two dynamics: first, the unfortunate experience of environmental determinism within Geography in the early 1900s; and second it reflects a critique of the hazards tradition which treated human societal response to environmental hazards in a mechanistic fashion (see Watts 1983). From a political ecology perspective, the effect of environmental change on society (including conflict) is always socially mediated, and environmental factors are generally considered as context (or consequences) rather than cause (see Bassett 1988).

In contrast, researchers from peace and conflict studies have often sought to determine the causal effects of environmental change, most notably in relation to the concept of 'resource scarcity', whether applied to land, renewable resources or 'strategic' fuels and minerals (Homer-Dixon 1991; Lesser 1989; see Koubi et al. 2014). As a result, to date the engagement between political ecology studies and peace and conflict studies is often focused on critiques of environmental determinism and reductionist positivist methodological approaches. This is particularly clear in debates about the possible role of climate change in

\footnotetext{
${ }^{2}$ Google Scholar search conducted on 30 January 2018 using search terms: "political ecology" with "conflict" (42,500 hits), or "power" (55,400 hits), or other key concepts (justice, gender, race, inequality, violence, peace).
} 
causing conflict, which we discuss in detail below (see Benjaminsen et al. 2012: Selby and Hoffman 2014). In parallel, peace and conflict studies have at times criticized political ecology studies for their lack of systematic analysis, reliance on single case-based anecdotal evidence, and overemphasis of social factors when compared to environmental ones. Yet, as discussed below, both fields encompass diverse conceptual perspectives and have broadened their methodological approaches, making them amenable to greater connections and mutual improvements.

While this article is not arguing for a return to environmental determinism, it suggests that political ecology can benefit from a better understanding of peace and conflict studies; furthermore, peace and conflict studies can be enriched via greater engagement with political ecology, especially in order to develop analyses of the dynamic interplay between socio-environmental changes and conflicts. Crosspollination seems all the more important because many conflicts are now interpreted through the lens of 'geo-politics' - the politics of earth itself. Further, this is important in the context of the rise of the socioenvironmental justice agenda, fostered by grassroots movements and inter-governmental appeals to develop more socially just and environmentally sustainable relations across the human and non-human world, including in terms of peacebuilding (Lederach 2017).

In this article, we seek to contribute to debates about the concepts, methodological approaches and major findings on conflicts by political ecologists, and the possible avenues for cross pollination with peace and conflict studies. We recognize that these two fields are highly diverse, with a history characterized by multi-disciplinarity and theoretical pluralism (Barash and Webel 2017; Robbins 2012). In this respect, our portrayal of these two fields is somewhat reductionist and supports a 'canonical' view reflecting already well-acknowledged and highly-cited works and authors. To focus our analysis, we primarily examine the topic of environmental change and conflict which, along with the theme of 'resource wars' (see Korf 2011; Koubi 2014; Le Billon 2013), received the most attention from both fields and produced some of the main interactions between them. As such, our contribution here remains a preliminary comparison and an initial, focused, foray into the potential of greater conversation and collaboration across these two fields. Political ecology can make specific and original contributions to our understandings of struggles over resources and the environment (Neumann 2014; Turner 2014, 2016). But it can also can gain from a more systematic engagement with peace and conflict studies, while the latter can integrate some of the former's insights, not only in terms of conflicts over resources and the environment, but also more broadly in engaging with socio-environmental relations and materialities (Bakker and Bridge 2006; Mann 2009).

The article is structured around two main parts. Following this introduction, we contrast political ecology and peace and conflict studies in terms of their conceptual and methodological approaches, highlighting some of their key contributions with regard to environmental and resource-related conflicts. In section 3, we discuss the value of deeper engagement between these two approaches, notably with regard to conflicts over renewable resources, extractive sectors, and in relation to climate change. We conclude with a call for deeper integration of political ecology and peace and conflict studies in order to strengthen the contributions of both fields to the understanding of the interplay between conflict and environmental change.

\section{Contrasting political ecology studies and peace and conflict studies}

Political ecology and peace and conflict studies are both interdisciplinary fields, with a broad diversity of research traditions, theoretical foundations, and methodological approaches. Here, we seek to bring out some of their more general characteristics, at the risk of oversimplification. The objective is not to give an exhaustive description of each field (for overviews, see Ramsbotham et al. 2016; Robbins 2012; Webel and Galtung 2007), but rather to contrast them in broad terms to better identify potential linkages and synergies (as discussed below in section 3).

\section{Conflicts}

The term 'conflict' is broadly understood as a contested incompatibility: the interaction of parties perceiving their goals as incompatible and engaging with each other through persuasion, arbitration, or 
coercion (Folger et al. 1996). Conflicts relating to the environment, then, are generally defined as a contested incompatibility between groups in relation to ecological systems. Such a definition, however, raises a number of issues. First, it remains vague about the relationships between conflicts and the environment, including whether conflicts occur over environmental goods and values, as a result of environmental change, or in relation to the (mis)use of natural resources (Frerks et al. 2014; Libiszewksi, 1991). Second, it reproduces reductionist dualism - social subjects versus environmental objects - rather than encompassing a wide range of co-construction processes, between the material and the representational, that enable richer and more nuanced examinations of conflict processes through their relational and hybrid dimensions (Ioris 2015; Li 2013; Swyngedouw 1999). Third, it risks portraying conflicts as an outcome of incompatibility among protagonists, rather than as a process through which incompatibility emerges, including as a result of various forms of violence (Springer and Le Billon 2016; Tyner and Inwood 2014). Finally, such a definition is 'symptomatic', in the sense that it does not theorize why incompatibilities occur or how conflict processes unfold. In this regard, whereas political ecologists often conceptualize conflict as a recurring historically-driven and multi-scalar socio-environmental process, peace and conflict scholars often operationalize conflicts as a discrete event bound by narrower spatial and temporal boundaries.

More generally, both fields engage with a wide range of environment-related conflicts, including conflicts over the definition, control, management, use and disposal of resources, ecosystems and landscapes, at a diversity of scales. The conflicts examined can be about biodiversity conservation or industrial processes, and their inter-connections. The types of conflicts are also highly diverse, ranging from interpersonal tensions within households to full-scale wars. Whereas political ecology has generally focused on community-level conflicts involving inter-personal forms of violence shaped by structural inequalities, peace and conflict studies have mostly examined higher scales of conflicts, including international and civil wars. Yet, as mentioned above, both fields are wide and have engaged with a broad diversity of conflict processes and outcomes.

\section{Genealogies}

Political ecology studies emerged as a significant body of scholarly work in the late 1980s, mostly through a combination of Marxist political economy and cultural ecology, to demonstrate the importance of uneven power relations and politics within environmental degradation processes and struggles over resources (Robbins 2012). Political ecology offers a distinctive approach to understanding conflicts over resources and environmental change, because it is historically grounded, field-based, and generally engages with both the structural and social dimensions of uneven power relations.

Political ecology is often less universalizing and deterministic than more mainstream political science and peace and conflict studies perspectives, in part because of its ethnographic methods which emphasize contingency and hybridity - especially when dealing with the 'materialities' of environmental or resource conflicts (Bakker and Bridge 2006; Turner 2004). Political ecology also departs from much of the environmental sciences, through its attention to the political dimensions of socio-environmental change and its concern for social justice (Forsyth 2008; Paulson et al. 2003). Political ecology's core strengths, as Tschakert (2012: 144) summarizes,

...lie in understanding the contestation of inequalities, marginalization, and injustices in access to and control over resources, neoliberal politics of environmental change, and dominant environmental narratives, while incorporating new insights from development ethics, feminist social theory, and resilience thinking.

As argued below, political ecology engages with conflict not only as an expression of contested incompatibility between resource users, but also as a process challenging uneven power relations. As such, conflicts not only constitute key identifiers of 'case studies' and entry points into environmental and 
resource politics, but also processes reworking socio-natural relations and calling upon political ecologists to 'give a voice' and frequently 'take sides' in favor of the 'victims'; an ethically engaged positionality which raises challenges and responsibilities (Jarosz 2004; Peluso 2002; Rocheleau 2008; Watts and Peet 2004).

Peace and conflict studies arose in the late 1950s, essentially as attempts to more systematically understand and (later) quantitatively demonstrate the factors and mechanisms behind conflicts and their mode of resolution, mostly in order to promote a more socially just and sustainable peace (Galtung 1969; Richardson 1960; for an overview see Ramsbotham et al. 2016). Peace and conflict studies have made distinctive contributions to research on conflicts over resources and environmental change, mostly in the form of medium- $\mathrm{N}$ comparative case studies and large- $\mathrm{N}$ statistical analyses (see below).

Whereas political ecology started with the impacts of uneven power relations and conflicts on resource access and environmental change (e.g. Blaikie and Brookfield 1987; Wolf 1972), peace and conflict studies mostly engaged with trying to understand how resources and environmental change can drive conflicts, or even as causes of conflicts (for example, Collier and Hoeffler 2005; Homer-Dixon 1999). This engagement has focused in particular on the ways that resource scarcity can induce conflicts. One of the most high-profile and recent examples of this is in critiques of claims that climate change plays a causal role in producing or deepening conflicts. Furthermore, it is in these debates that we see the greatest levels of engagement between political ecology and peace and conflict studies (see below).

Political ecologists have criticized the field of peace and conflict studies for its reductionism, because of its focus on comparative methods and because the field seeks to draw out general/generalizable conclusions rather than in-depth particularities. In contrast, political ecology studies have often provided empirical material for data coding by peace and conflict studies, yet they have been criticized for their anecdotal approach and lack of systematic analysis. Beyond these limited exchanges, some scholars have attempted to bridge the gap, to combine approaches, to put findings into conversation, and have tried to develop a fresh and more nuanced perspective on the role of environmental change in conflicts. For example, in the work of some authors, such as Benjaminsen et al. (2012), there has been a specific attempt to bring the fields of political ecology and peace and conflict studies into conversation with each other. A second body of literature, including Selby and Hoffmann (2014) and Selby et al. (2017a,b), takes what can be thought of as a 'political ecology type' approach to understanding environment-conflict dynamics, but they do not identify as political ecologists or as scholars of peace and conflict studies. The aim of these studies is to undertake a systematic analysis and to critique other bodies of literature, most notably on the proposed causal links between climate change and conflict (as discussed below). In this article, we aim to bring some of these diverse strands together, to encourage greater engagement between them, and with aim of enriching political ecology and peace and conflict studies.

\section{Contrasting theories}

Political ecology perspectives on conflict draw mostly from Marxist, feminist and post-colonial theories of conflict, according to which conflicts result from social structures and imaginaries shaping differentiated environmental access and responsibilities (Bryant and Bailey, 1997; Robbins 2004; Rocheleau 2008). These social structures can notably be class-based, racialized, and gendered. The unfair configurations of access to the environment, and distribution of burdens and benefits from resource-based production and environmental change, are frequently rejected and thus "become the source of political struggles" (Robbins 2004: 201). Political ecology situates resource access - including property regimes, the bundle of property rights defining control over, access to and use of environmental goods - at the core of many of these configurations (see for example, Turner et al. 2011); political ecology sees conflicts as frequently resulting from challenges to 'traditional' regimes, such as the privatization of commons or the imposition of new conservation rules (Bassett 1988; Ribot and Peluso 2003; Rocheleau 1995).

Conflicts not only result from material changes in the environment and access to resources, but from changes in imaginaries over the environment and resource users. Development and conservation imaginaries often construct new developmental or environmental subjectivities which can result in conflict 
between diversely represented stakeholders, including within the 're-invented' communities and social movements (Wolford 2004). In this respect, conflicts are not only about regaining control over the environment, but also about redefining self-subjectivities, a form of alter-geopolitics (Koopman 2011) through which identities become intimately tied-up to alternative rights and responsibilities (Escobar 1998). This complex interplay between social structures, resource-user groups, and the environment not only fosters conflicts, and various forms of resistance and repression, but also a wide range of social relations including consent, collusion and cooptation (Brock and Dunlap 2018; Horowitz 2011).

Within this perspective, environmental justice increasingly constitutes an important concept (and goal) for political ecology, although political ecologists have tended to be less attentive to the types of (in)justice that they are documenting or have sought to address. Environmental justice emerged to demand the end of discriminatory environmental risk allocation - and associated economic and health impacts disproportionally affecting certain communities and segments of society (Bullard 1994). The concept then came to involve distributive and procedural conceptions of justice, as well as notions of justice based in recognition, participation and capabilities (Schlosberg 2007). Environmental justice approaches are particularly sensitive to historical processes of environmental degradation and resource dispossessions, to social stratification through racialization, classism, and gender-biases, and to the abilities of marginalized groups to resist injustices (EJOLT 2013a; Pellow et al. 2001). As such environmental justice struggles form a key topic, and a participatory objective, of political ecology - a scholarly approach seeking to provide an alternative to 'apolitical' ecology, mostly through a combination of 'ecologically rooted social science and the principles of political economy' (EJOLT 2013b; Forsyth 2008; Robbins 2012).

Rather than naturalizing conflicts through environmental analysis, political ecology explores the politicization of the environment via conflicts (Martinez-Alier 2009; Robbins 2012). This perspective represents a crucial departure from neo-Malthusian concepts of 'environmental conflict' supporting depoliticized concepts of environmental scarcity (or abundance) 'naturally' triggering conflicts - generally of the 'violent ethnic' kind. Political ecology engages conflicts not only through a search for causes and a description of symptoms, but emphasizes - or even promotes - their transformative and emancipatory effects in challenging structural and cultural forms of violence, done to people and the non-human (Watts and Peet 2004). This contrasts with mainstream representations depicting conflicts as simply negative, and using for example terms such as 'riots' instead of 'demonstrations' in an attempt to criminalize aggrieved victims of inequalities as 'troublemakers' and delegitimize their struggles (Zalik 2011). As pointed out by Velicu and Kaika (2017), concepts of environmental justice and the praxis of political ecologists (and indeed, peace and conflict scholars) also need to go beyond research to promote recognition, participation, and redistribution for marginalized populations, and should seek to bring about new social imaginaries and more radical forms of political equality.

Broadly, peace and conflict studies is a deliberately interdisciplinary field, and has developed a range of approaches to the question of what constitutes or drives conflict, how conflicts differ from violence, and whether the main focus should be on armed conflict (see Cochrane 2008; Jabri 2013; Kalyvas 2006; Ramsbotham et al. 2016; Rogers 2013; Webel and Galtung 2007). Ramsbotham et al. (2016) contend that we can understand conflict as produced by incompatible goals by different parties; such conflicts can be symmetrical, in which parties are roughly equal, or they can be asymmetric, in which one party is less well-resourced and is less powerful. This latter way of thinking of conflict fits well with the ways in which political ecologists are generally concerned with conflicts experienced by more vulnerable and marginalized communities (for example, see Martinez-Alier et al. 2016).

Peace and conflict studies further separate out different scales of conflicts. There are wellestablished debates in the field on the question of what constitutes appropriate thresholds in defining and labeling an 'armed conflict': number of battle deaths, use of the term deadly violence to denote one-sided or asymmetric conflicts, as well as important distinctions made between the peace studies, peace-building and conflict resolution approaches and more recent debates about conflict management, conflict transformation, conflict engagement and even conflict containment (Cochrane 2008; Jabri 2013; Ramsbotham et al. 2016). 
It is not possible to cover the very wide field of peace and conflict studies in this one article, but a much more thorough engagement with these rich debates on how to define and understand conflict can be useful to political ecologists seeking to refine their own analyses; to date they have not been well reflected in the field of political ecology, and this would allow for further and more nuanced reflection on what political ecologists mean by conflict, violence and struggle.

Peace and conflict studies has a long tradition of developing theories of conflict, which can be (further) drawn upon to enrich political ecology (Bohle and Fünfgeld 2007). Four initial examples of work from peace and conflict studies might produce fruitful entry points: Galtung, Lederach, Azar, and 'environmental peacebuilding.' The work of Johan Galtung and of John Paul Lederach can serve as two different, but useful, initial entry points and sources of common ground. Like political ecologists, these two leading peace and conflict studies thinkers both point to the need to understand and address the complex underlying structural factors which produce conflict, such as poverty and injustice. While Galtung (1996) is more concerned with global dynamics, Lederach (2005), points to the need to analyze local contexts and lived experiences, which is also central to the work of so many political ecologists. Furthermore, Edward Azar's (1990) approach to understanding protracted social conflict as rooted in a deprivation of human needs may also provide an entry point for better engagement between the two fields. His focus on trying to understand the struggles of groups for basic needs such as security, recognition, and the ability to participate in political and economic life has some resonance with the social justice concerns of political ecologists (also see Azar and Burton, 1986; Ramsbotham 2005).

Finally, within peace and conflict studies, environmental peacebuilding attempts to integrate socially just forms of natural resource management into conflict prevention and post-conflict peacebuilding. Environmental peacebuilding is anchored in the idea that areas of common environmental interest and the need for cooperation over transboundary environmental resources can foster peaceful relationships between neighboring states that previously been engaged in armed conflict (Barquet, Lujala and Rød, 2014; Conca and Dabelko 2002; Conca and Wallace 2002; Krampe 2017). ${ }^{3}$ For example, a recent comparative study by Ide (2018) examines six cases which display the features of having terminated interstate rivalries, engagement in transboundary cooperation, and involvement in freshwater agreements (between Rwanda-Uganda-DRC, Tanzania-Uganda, Mauritania-Senegal, and El Salvador-Honduras). He concludes that cooperative environmental agreements can have a positive impact on reconciliation between rival states. This, however, overlooks the body of work in political ecology that criticizes transfrontier conservation efforts as a producer of new forms of conflict and environmental struggles because of their neoliberal underpinnings (see discussion of transfrontier peace parks below). Environmental peacebuilding is a developing field, and it could be a growing area for future dialogue between political ecology and peace and conflict studies. This is in part because environmental peacebuilding contests the more common argument that the environment (or environmental change) produces conflict; instead it is argued that the environment can be a source of cooperation, conflict reduction and eventually, the creation of peace (Ide 2018).

\section{Contrasting methodologies}

Political ecology methodologies are diverse, but most derive from techniques deployed by political economists, historians, anthropologists and ecologists (Neumann 2014). Ethnographic approaches involving long-term fieldwork at (often single) research sites and a deep knowledge of local cultures are common, especially for doctoral theses and subsequent research monographs. Yet, especially with regard to the study of conflicts, political ecology methods also seek to achieve trans-scalar analysis, so as to document and understand the diversity of actors and processes involved (Peluso and Watts 2001). For this purpose, approaches have included multi-sited ethnographic work or at least in-depth interviews, and commodity chain analysis.

\footnotetext{
${ }^{3}$ https://environmentalpeacebuilding.org (accessed 20/01/18)
} 
The importance of historically-grounded analysis in political ecology implies the use of diverse techniques such as oral histories (often a must for conflicts involving marginalized populations lacking selfwritten archives), aerial imagery time-series, archival work, or paleo-botany (Davis 2007; Fairhead and Leach 1996). This empirical material is then used critically to assess the impacts of colonial processes or pre-existing resource use. Given the importance of documenting and deconstructing dominant and subaltern narratives and practices, methods also include the recording and collection of texts, images, ecological practices, and landscapes. Participatory observation and action research among socio-environmental movements are quite common, especially when political ecologists need to gain trust, demonstrate commitment, and feel a responsibility to contribute to their struggles (Sultana 2007). This positionality, in turn, often raises accusations of bias, to which some political ecologists respond by ethical - if not foundational - commitments to actively contribute to the politicization of environmental issues.

Peace and conflict studies is a deliberately interdisciplinary field, and its methods are also diverse, including quantitative, qualitative and mixed empirical analyses, through to a more recent engagement with critical theory and post-structuralism (Patomäki 2001; Ramsbotham et al. 2016). There has been more progress made over the past fifteen years to bring greater disaggregation to variables used in statistical analyses (Bretthauer 2015; Ide 2017). There are several arenas of divergence, and two brief examples are the use of databases and the identification of environmental change as a cause of conflict.

The environmental security strand of peace and conflict studies has drawn extensively on qualitative and quantitative datasets. These databases notably include the Peace Research Institute of Oslo (PRIO) grid database (Tollefsen et al. 2012), ${ }^{4}$ the Armed Conflict Location and Event Data Project (ACLED), ${ }^{5}$ and the Uppsala Conflict Data Programme (UCDP). ${ }^{6}$ Over time such databases have become more finely tuned and nuanced, allowing researchers to rely not only on aggregate data at a country level, but also to focus down on incidences of conflict in particular locations at the sub-state level, yet generally still according to a few pre-determined and workable variables. While such an approach brings greater clarity, and enables more 'rigorous' assessments, there are still debates about the criteria used, the variables chosen, and the possible oversimplification of local level contexts (Buhaug 2010a; Buhaug et al. 2011; Raleigh et al. 2014; Tollefsen, et al. 2012). There are two issues.

Firstly, this differs significantly from political ecology, which tends to be rooted in a deep ethnographic understanding of particular places, with their specific histories, actors, affects, and socioenvironmental relations. As such, while the databases used by the quantitative strands of peace and conflict studies have become more detailed and nuanced, they have yet to capture some of the dimensions examined by political ecology (e.g. history, relationality, hybridity). These differences, in turn, often have implications in terms of analyses of causality and pathway processes, with the search for statistical patterns and unidirectional causality flows for peace and conflict studies, compared to iterative, contingent, and variegated processes for political ecology.

Secondly, in peace and conflict studies environmental change can be identified as a causal factor (Collier and Hoeffler 2005; Homer-Dixon 1991, 1999). In contrast, political ecologists have offered robust critiques of this argument, offering challenges the claim that there is a causal link between environmental change and conflict (see for example, Benjaminsen et al. 2012; Hartmann 2001), as have some peace and conflict studies researchers (Buhaug 2010a; Gleditsch 2010; Slettebak, 2012). Greater engagement with these critiques from within peace and conflict studies can enhance the challenges from political ecologists around the idea that environmental change is a cause of current conflict, or a potential security threat in the future.

\footnotetext{
${ }^{4}$ http://grid.prio.org (accessed 10/01/18)

${ }^{5}$ https://www.acleddata.com (accessed 10/01/18)

${ }^{6}$ http://ucdp.uu.se (accessed 10/01/18)
} 


\section{Contrasting contributions}

Political ecology is in part about recognizing the political dimensions of environmental and resource issues; and, thereby, engaging with the conflicts that come to constitute much of the collective decisionmaking processes contesting a pre-existing status quo or consensus. Recognition of the political character of environmental issues, as Paul Robbins (2004: 173) points out, includes the 'politicization' of environmental problems "when local groups...secure control of collective resources at the expense of others by leveraging management interventions by development authorities, state agents, or private firms"; and the 'ecologization' of pre-existing conflicts as a result of "changes in conservation or resource development policy." This argument, according to Robbins, is based on three lessons drawn by political ecologists from feminist theory: emphasizing the effects of labor and power divisions unevenly distributing "access and responsibility for natural goods"; from property research, understanding "property systems as complex bundles of rights that are politically partial and historically contingent"; and from critical development studies, showing that development activities are "rooted in specific assumptions about the class, race, and gender of participants in the development process, often resulting in poorly formed policy and uneven results" (2004: 173).

In this respect, many political ecologists hold a stratified notion of society structured by uneven power relations. From this starting point, as Raymond Bryant and Sinead Bailey suggested, many political ecologists consider that changes "will not occur without considerable struggle since they necessitate the transformation of a series of highly unequal power relationships upon which the present system is based" (1997: 3; see also, Holifield 2015). Many political ecologists are thus not only interested in the causes and various forms of conflicts, but also in their emancipatory potential, as discussed below.

By understanding conflicts and contestations in a broad sense - and not waiting to see more visible direct manifestations of physical violence - political ecologists express a sensitivity that better captures the various tensions and grievances at play, as well as the various forms of violence and modes of resistance involved. By recognizing distinct ontologies, values and practices, political ecologists also allow for new understandings and solidarities. In contrast to most studies focusing on the relative scarcity or abundance of resources, political ecology approaches have thus sought to provide nuanced and historically grounded analysis of uneven power relations and conflicts around natural resources, understanding violence "as a site-specific phenomenon rooted in local histories and social relations yet connected to larger processes of material transformation and power relations" (Peluso and Watts 2001: 5; see also, To et al. 2014).

The distinctive contributions of political ecology are anchored in drawing out a more nuanced understanding of these wider contexts which drive resource-related conflicts, while being attentive to 'local' power dynamics. This has been the case for studies of land-based (Fairhead et al. 2012; Le Billon and Sommerville 2017; Li 2014; Unruh 2003) and extractive projects (Bebbington and Bury 2014; Perreault 2013), especially for those involving local livelihood disruptions, internationally traded commodities, and trans-scalar power networks. This is also the case with the body of work on 'Peace Parks' by political ecologists, who sought to offer critical interrogation of the claims that environmental cooperation would lead to a reduction in conflict; rather their work showed that the establishment of vast peace parks in Southern Africa produced new and intense conflicts, in part because of their underlying neoliberal logics (see Büscher 2010, 2013; Duffy 2006). Furthermore, more recently political ecologists have been at the forefront of debates about the growing intersections between biodiversity conservation and violent conflict (Asiyanbi 2016; Büscher and Ramutsindela 2016; Duffy 2016; Lombard 2016; Marijenen and Verweijen 2016; Massé and Lunstrum 2016; Ybarra 2016).

Following on from this, political ecology approaches can help contribute to peace and conflict studies in several ways. First, political ecology analysis helps reconceptualize scarcity, abundance and dependence temporally through historically-grounded analyses. Such reconceptualization is also done from a critical perspective, which situates scarcity, abundance and dependence within uneven power relations and resource entitlements that reflect the antagonizing effects of conflicts on social identities. As such 'resource scarcity', for example, is not considered as a 'factor' influencing the likelihood of conflict, but 
rather as the material and representational outcome of historical socio-natural processes. This focus on hybridity and process helps demonstrating how violence - as a process rather than simply an event (Tyner and Inwood 2014) - not only perpetuates or reshapes conditions of access and control over resources, but is also transformative of resources and environments. A potential contribution of political ecology in this regard is to further assist in the decolonisation of understandings of resource conflicts, notably by challenging ontological dualisms and accounting for past (and present) colonial praxis (Schulz 2017).

Second, political ecology questions not only when and where conflicts are 'taking place', but also at what scales conflict processes unfold. By recognizing the chronic and multi-scalar character of many environmental and resource-related conflicts, political ecology helps expose the structural dimensions of many conflicts and the hidden responsibilities that contribute to their more visible expressions. Rather than simply 'operationalizing' conflicts through data points explicitly capturing conflict 'events', such as the geographic coordinates of a protest, political ecology approaches strive to expand the range of relations and actors involved in conflict processes. For this, political ecology studies draw notably from critical political economy perspectives and commodity chain analysis methods (Greenberg and Park, 1994; Huber 2017), but also semiotics capturing the representational dimensions of conflict processes (Martinez-Allier 2009; Moore 1993).

Third, political ecology studies generally account for a broader range of violence than geopolitical and mainstream political perspectives, thereby grasping a wider and more nuanced set of relations between conflict processes and forms of violence. The concepts of 'silent violence' of policy-induced famines (Watts 1983), of the 'slow violence' of pollutants (Nixon 2011), and of the 'gendered violence' of patriarchal land tenure systems (Lahiri-Dutt 2015) have contributed to a deeper understanding of what violence consists of, and the underlying structural and cultural dimensions involved.

Fourth, political ecology recognizes resources and the environment as complex socio-material objects reflecting a diverse range of practices and discourses, but also as subjects endowed with certain forms of agency. Here, it draws from actor-network theory (Latour 2014; Staddon 2009). If such a perspective opens up to the risk of depoliticized environmental determinism, political ecology's strong emphasis on relationality helps avoid some of the excesses of 'agentic' nature (Castree 2002), whereby nature is attributed with a strong level of (intentional) agency, while its practitioner's embodied engagement in the field can help 'feel' the 'vitality and life' of things (Bennett 2009; Tolia-Kelly 2011).

Finally, political ecology gives attention to the discursive dimensions of ecological processes and resource sectors, notably the 'regimes of truth' - or historically contingent mechanisms producing quasihegemonic truth discourses - that sustain and seek to legitimate resource-based processes of capitalist accumulation in the form of enclosure of the commons and other exclusive rights of access (Robbins 2012). This covers not only commodification processes explaining how 'things' become resources or commodities defined by their use and exchange values, but also fetishization processes including the imaginative aspects of resource production and consumption affecting power relations, conflicts and associated forms of violence (Cavanagh and Benjaminsen 2014). These aspects may be inserted within peace and conflict studies through constructive approaches and the 'visual turn' recently experienced in the broader fields of political sciences and international relations.

Escobar (2006) has rightly pointed to the importance of accounting for cultural differences and distinctive ontologies of nature and resources in explaining environmental conflicts (see also, Sullivan 2017). Such "worlding" also extends to the register of expressions involved in conflicts, with MartinezAlier (2003: viii) reminding us that "ecological conflicts are fought out in many languages." As Mario Blaser (2013) argues it is important to: first to take time to understand what the conflict is about (it may or may not be about the environment, while 'the environment' itself may be understood very differently); second, to recognize the possibility of ontological conflict, while not assuming that because cultural differences exist, ontologies must differ; and third, to focus on performance rather than group ascription; and, overall, seeking to maintain a 'pluriverse' - and in particular a diversity of contrasting interpretations and relations with the non-human - as well as an openness of outcomes, rather than accurate accounts that 
risk providing "just another cultural perspective." Instead of situating environmental change and resources as 'drivers' of violent conflict, political ecology considers contingent relations between uneven resource entitlements, resource exploitation and consumption patterns, and forms of violence and conflict processes.

The distinctive contributions of peace and conflict studies could be used to enrich political ecology in both conceptual and methodological ways. First, it would be useful for political ecologists to engage with the broad conceptual approaches to understanding and interpreting conflict, as discussed above. Peace and conflict studies have offered systematic, yet often nuanced and at times culturally-grounded, conceptualization of conflicts and conflict-related narratives and praxis. Such contribution can not only help to better categorize conflict types, but also more systematically characterize the (iterative) stages of conflict processes, and more clearly disaggregate their various causal factors and dimensions - including for the purpose of examining the most prominent arguments of peace and conflict studies (e.g. resource scarcity and high population density leading to social fragmentation and conflicts) and political ecology (e.g. uneven power relations and high inequalities leading to socio-environmental conflicts) (see for example Østby et al. 2011).

Second, peace and conflict studies have experimented with a broader range of methodologies than political ecology, and have been subject to robust methodological critique (Gleditsch 1998). Novel contributions have resulted from the use of team-based medium- $\mathrm{N}$ comparative analysis of individual case studies, statistical analysis using spatially disaggregated data and multi-layered geo-referenced information, as well as field-based natural experiments (Ide 2017). These have not been without controversy, in part as a result of the conceptual assumptions and inductive design of these approaches. Yet reflecting on, or integrating some of these approaches may also assist political ecologists in refining their analyses and moving beyond understanding specific place-based conflicts towards wider patterns, without falling into the pitfalls of environmental determinism.

\section{Connecting political ecology studies and peace and conflict studies}

There have been some important attempts to bring political ecology and peace and conflict studies together to explore and challenge claimed links between environmental change and violent conflict (e.g. Benjaminsen et al. 2012; Buhaug et al. 2015); further there are studies, which are not defined by the authors as political ecology per se, but which can be thought of as following a political ecology approach because they seek to challenge and critique the argument that environmental change can be a cause of conflict (such as Selby et al. 2017a). We discuss opportunities for building connections, including through existing critiques and further research agendas, in three domains of environmental conflict: renewable resources, the extractive sectors, and climate change.

\section{Looking for connections}

There are relatively few direct integrations of political ecology in peace and conflict studies. A search of four of the top journals for peace and conflict studies, Journal of Peace Research, Cooperation and Conflict, Security Dialogue and the Journal of Conflict Resolution, yielded a total of only 13 articles mentioning political ecology in their analysis. This does not mean that the journals do not articles on environmental issues - they have done so for a long time (see for example, Gjessing 1967) - but it does indicate that political ecology as an approach to analyzing the interplay between environmental change and conflict has yet to make significant inroads into peace and conflict studies. ${ }^{7}$

Similarly, a search of studies mentioning 'political ecology' and citing Galtung returns 595 results on Google Scholar, $0.8 \%$ of the total hits for 'political ecology', suggesting that Galtung's foundational work

\footnotetext{
${ }^{7}$ Questions around the interplay between conflict and environmental change have been (and continue to be) debated in journals which fall outside peace and conflict studies such as Climatic Change, Geoforum, Geopolitics, Nature, Political Geography, Proceedings of the National Academy of Sciences and Science, each of which have carried high profile articles or special issues on the topic.
} 
within peace and conflict studies is not frequently integrated within political ecology studies - with only two articles being in the Journal of Political Ecology. Bringing the two fields into conversation with each other would undoubtedly develop and strengthen the ways that peace and conflict studies address the interplay between conflict dynamics and global environmental change and develop the ways political ecologists define conflict. It would be particularly useful for peace and conflict journals to take up these issues more fully in order to help develop political ecology approaches to understanding the nature and drivers of conflict. Here, we first provide a few illustrative examples drawn from recent high profile works, which could benefit from a more thorough and nuanced approach provided by political ecology.

\section{Environmental security and conflicts over renewable resources}

The environmental security approach seeks to explain how environmental change, natural resources and armed conflict are linked (see Homer-Dixon 1999; Koubi et al. 2014). Environmental security analysts seek to establish a link between natural resources, environmental change and violent conflict. Homer-Dixon (1999) argues decreasing supplies of controllable resources, such as clean water and good agricultural land will provoke 'simple scarcity' conflicts or resource wars; that large population movements caused by environmental stress will induce group identity conflicts and especially ethnic clashes; and that severe environmental scarcity will increase economic deprivation and disrupt key social institutions which would cause deprivation conflicts such as civil strife and insurgency. Homer-Dixon stops short of claiming a direct causal link between environmental degradation, scarcity and conflict, but instead suggests that environmental scarcity intersects with other conflict-producing dynamics. It is important to note that environmental security encompasses a much wider range of arguments than those posed by Homer-Dixon (Floyd and Matthew 2013), including notions of the conflict trap (Bannon and Collier 2003), resilience (Schilling et al. 2017), and impacts relating to the built-environment (Sowers et al. 2017).

Environmental security draws on particular understandings of environment-society interactions, which view violence as an outcome of natural resource scarcity, thereby acting as a 'natural check' on population growth. Political ecologists, have been prominent critics of environmental security analyses and especially of Thomas Homer-Dixon and the Toronto Group, as well as the Swiss Group under Günther Baechler (Baechler and Spillman 1996). Peluso and Watts (2001) for example stress that environmental change in itself does not increase the risk of violent conflict per se and have suggested that environmental security, especially Homer-Dixon's reading, is informed by neo-Malthusian frameworks (see also Benjaminsen et al. 2012; Mehta 2010). It is important to note that environmental security, and especially the methods and approach used by the Toronto Group have been criticized from within peace and conflict studies as well, notably through arguments that environmental security is neo-Malthusian and that a case study approach means that the findings are not generalizable (Buhaug 2010b; and Butler and Gates 2012; Gleditsch and Urdal 2002).

Such criticisms can be further developed and strengthened via engagement with political ecologists who also question the neo-Malthusian tone of environmental security, yet stress the value of detailed case studies and call for a richer and deeper ethnographic understanding of conflicts. Seeking to find a common ground, Ide (2015) uses a fuzzy-set qualitative comparative analysis based on literature from case studies to address ambivalent findings on the major determinants of violent escalation of conflicts over scare renewable resources. While promising, Ide (2015) suggests that scholarship would gain from using more disaggregated variables, interaction terms, and broader samples.

Water security and conflicts over water have been prominent topics of study for both political ecology and peace and conflict studies (Cook and Bakker 2012; Sneddon et al. 2002). Peace and conflict studies often focused on demonstrated the (in)validity of claims about 'water wars' emerging, especially armed conflicts between states sharing rivers (e.g. Furlong et al. 2006), and contests between states over hegemonic transboundary water governance (Zeitoun and Warner 2006). Several peace and conflict studies have nonetheless engaged with issues of scale (Böhmelt et al. 2014), representation (Menga 2017), and broader socio-political processes (Zeitoun et al. 2017) that reflect the more common approaches of political ecology studies emphasizing the complexity and specificities of time- and place-based hydro-social cycles 
(Boelens et al. 2016; Sneddon et al. 2002; Swyngedouw 1999), including the importance of water's multiple ontologies in many conflicts (Yates et al. 2017). As such, some studies from both fields demonstrate the central role of dominant framings of water and associated hierarchies in struggles over water (Boelens 2014; Grech-Madin et al. 2018).

\section{Conflicts over extractive resources}

Extractive industries and associated resources have provided a further topic of study for both political ecology and peace and conflict studies. The major focus of peace and conflict studies has been on 'resource wars', including inter-state resource competition, especially with reference to the second Gulf War in 1991, the US invasion of Iraq in 2003, and renewed tensions in the South China seas (Klare 2012), but also the motivation and financing of rebellion (Collier and Hoeffler 2005; Le Billon 2008). The most robust findings of the positivist quantitative literature in this domain tend to suggest a likely relationship between on-shore oil dependence and armed conflicts, one which remains sensitive to specifications and mediated through other intervening variables such as oil income level, regime type and ethno-religious fragmentation (Lujala 2010; Ross 2015).

Yet, many of studies of 'resource wars' have been criticized by political ecologists for their reductionist understanding of the deleterious impacts of resource wealth and dependence on the quality of institutions, the risk of economic shocks, and the motives and opportunities for armed rebellion, based in part on narrowly focused narratives about the prominent role of 'conflict resources' (Le Billon 2013). Political ecology studies have also (re)directed attention to community-level conflicts over resource extraction, and in particular mining and fossil fuels (Bebbington and Bury 2014; Watts 2004), helping to demonstrate the diversity of actors, narratives, relationships, and practices involved (including within communities, authorities, and corporations), and the multi-scalar dimensions and various forms of violence associated with resource extraction.

As mentioned above, increased extractive activities in a broader context of contentious politics and concern for the environment and alternative development paths have led to a major increase in extractive conflicts during the last commodity boom. Peace and conflict studies have paid relatively little attention to this phenomenon, in contrast with political ecology studies. Whereas the former mostly focused on gathering empirical evidence of causal factors linking extraction with protests (Steinberg 2018), political ecology studies brought a wealth of in-depth cases studies and a more systematic detailed identification of socio-environmental conflicts characteristics (Bebbington and Bury 2014; Temper et al. 2015). Together, these two literatures have brought evidence of broad patterns and nuanced accounts of the various factors at play, including the characteristics of extractive activities, community dependency towards mining companies, political and economic marginalization, mutual (dis)trust in and among communities, companies, various levels of government authority, and extra-local alliances (Conde and Le Billon 2017).

\section{Climate change and conflict}

Both fields of political ecology and of peace and conflict studies have attempted to explain and debate the role of climate change in generating conflict. For example, Hsiang et al $(2011,2013)$ and Zhang et al. (2011) have been influential in developing the claim that incidences of civil conflict increased as a result of climate change. Peace and conflict scholars like Buhaug et al. (2014), Salehyan (2014) and Raleigh et al. (2014) contest these claims and point out that Hsiang et al. (2011) drew their deterministic conclusions from a review of 60 articles, but each of them used different units of analyses (including different spatial, social and temporal scales) and so they were not necessarily comparable (see also, Ide 2017). Buhaug et al. (2014) directly challenge the methodology and counter that the datasets do not prove a direct causal link between the experience of climate change and conflict (also see Buhaug et al. 2015; Gleditsch 2012; Slettebak 2012). Other peace and conflict scholars, such as Raleigh and Kniveton (2012) suggest that climate change in East Africa produces different kinds of conflict (civil versus communal) depending on whether it involves wetter or dryer conditions. 
However, although these analyses are critical of the determinism and methodology of research by Hsiang et al. (2011, 2013) and Zhang et al. (2011), their approach generally differs from political ecology because they focus on critically examining methods to establish causal links between environmental change and conflict, rather than addressing underlying structural factors or questioning the ways such causal links and adaptation mechanisms are framed in the first place (Benjaminsen et al. 2012; Taylor 2014; Tschakert 2012; Zografos et al. 2014). One exception to this is Raleigh et al. (2014) whose approach is consistent with political ecology; they argue that there is a danger in current debates of an overly deterministic approach, which disregards social processes and historical circumstances which explain the emergence of conflict; and further they point out that studies by Hsiang et al. (2011) and others do not allow for the ingenuity and adaptability of communities in coping with climate change.

Reviewing contributions to conflict and climate change debates from political ecology (and 'geography'), Abrahams and Carr (2017) conclude that these approaches challenge 'climate change as threat multiplier' narratives and the links made between climate vulnerability and conflict. Rather, political ecology studies point to the risks of climate adaptation mechanisms fostering conflicts and even to the possibilities of climate change contributing to peacebuilding. Furthermore, they suggest that grounded, nuanced and politically attuned analyses can provide more meaningful and actionable understandings than recommendations coming out of simplifying models. Indeed, the argument that climate change (in the form of severe drought) was a key causal factor in the Syrian war provides good example of how a political ecology approach can be important in debates about environment-conflict interactions. Selby et al (2017a) criticized Kelley et al.'s (2015) claim that climate change was a significant causal factor for the conflict in Syria since 2011. For example, data used by Kelley et al. (2015) covers an area called the Fertile Crescent that crosses several countries, not just Syria; and despite the claim that climate change-induced drought produced the conflict they do not include data on rainfall. Examining a wide array of sources, Selby et al. (2017a,b) conclude that there is no reliable evidence that climate change produced (or caused) the Syrian conflict, played a role in generating migration within Syria, or triggered out-migration from the region. Furthermore, Selby (2018) suggests that political ecology provides an appropriate framework for understanding the Syrian war precisely because it encourages locally specific and detailed investigations; he concludes that the war was produced by long-term structural factors such as serious water resource degradation, the collapse of an oil-driven agrarian development model underpinned by oil rents (which collapsed), and the specific histories in a contested border region.

\section{Conclusion}

Conflicts over resources and environmental issues constitute a major topic of enquiry within political ecology. Yet beyond this scholarly pursuit, political ecologists also see in conflicts a symptom of injustice and uneven power relations, as well as a potential process of emancipation and even 'liberation' for marginalized and oppressed populations and their ecosystems. Interpreting conflict through the lens of socio-environmental justice thus grants conflict a constructive potential, rather than a universally destructive one. Violence is not only seen as the brutal physical outcome of an escalating conflict, but as a situated and multidimensional process taking many forms and working throughout the various 'phases' of conflicts. This is a key contribution which political ecology can offer to the field of peace and conflict studies. In turn, political ecology can benefit from more engagement with conceptual debates in peace and conflict studies, especially theorizations of conflict and violence. Drawing in these vibrant debates would undoubtedly enrich the distinctive contribution of political ecology to understandings of environmental struggles. Furthermore, greater integration of methodological innovations, especially those pursued within peace and conflict studies, would add to the interdisciplinarity of these two fields of study.

We attempted through this article to contrast and further investigate potential linkages between political ecology and peace and conflict studies. We have drawn out several distinctive contributions of political ecology to the understanding of conflict, and highlighted the ways that political ecology studies aim to uncover and understand the causes and consequences of the uneven distribution of power relations. This often implies that political ecology seeks radical transformations of existing structures in order to 
produce a more just and sustainable world. As such, we suggested that political ecology allows for the development of new and distinct ontologies, values and practices, as well as encouraging new solidarities with more marginalised social groups. We also showed how political ecology highlights new forms of politics of mobilisation and resistance.

Turning to peace and conflict studies, there are several points of potential contact and opportunities for constructive engagement. Peace and conflict studies has a long tradition of developing conceptual understandings of conflict and of violence; the work of Galtung, Lederach, Azar and environmental peacebuilding approaches could be important starting points to develop the conversation between the two approaches. This could allow political ecology to refine its distinctive conceptual contribution to understandings of conflict; it could also assist peace and conflict studies to develop fresh approaches to understanding the interplay between global environmental change and conflict, moving it away from the current focus on environmental security and/or Malthusian scenarios. Peace and conflict studies have also developed sophisticated and increasingly nuanced and disaggregated empirical research methods that can provide traction within policy-making. Political ecology may benefit from some of these innovations, while avoiding the pitfalls of reductionism and offering additional arguments for those within peace and conflict studies who wish to critique the conclusions drawn by environmental security analysts using oversimplistic statistical approaches.

New directions for political ecology research on environmental and resource-related conflicts remain largely open, but some topics and approaches are demonstrating growing prominence, greater urgency, or promises of new theoretical insights. Within the confines of traditional topics, conflicts associated with the 'global land grab' and more generally with the 'green grab' have received much attention, notably with respect to more nuanced understandings of 'smallholder' dispossession by large-scale agro-industrial investments and food production regimes. Recent topics also include conflicts associated with urban political ecologies, dispossession and environmental degradation in 'emerged economies', broadly defined biopolitics in the 'Anthropocene', and the political ecology of 'degrowth'. Debates around 'speciesism' - or species-based prejudiced views and practices - and the ethics of the 'non-human', as well as conflicts around the environmental dimensions of 'new technologies' like nanotechnologies also offer avenues for further research. Methodologically, quantitative tools including GIS and statistical analyses seem to be making some headway to help complement mostly ethnographic material, while many bridges remain to be built with the approaches and findings of 'natural sciences.'

Finally, and perhaps most importantly, is the question of linkages with activist knowledge, including collaborative knowledge production and mobilization, but also active participation in environmental and resource struggles. Political ecology offers a distinctive approach to understanding conflict, which can clearly support the pursuit of environmental justice. Yet, to be effective, contributions from political ecologists need to be reflective of their positionality and unintended impacts. As such, engaged political ecology not only requires fine-grained analyses attuned to the nuances of power relations in conflict settings, but also prospective reflections on the (in)direct effects that scholarly interventions and participatory action research will likely produce.

\section{References}

Abrahams, D. and E.R. Carr. 2017. Understanding the connections between climate change and conflict: contributions from geography and political ecology. Current Climate Change Reports 3(4): 233242.

Asiyanbi, A.P. 2016. A political ecology of REDD+: property rights, militarised protectionism, and carbonised exclusion in Cross River. Geoforum 77: 146-156.

Azar, E. 1990. The management of protracted social conflict: theory and cases. Aldershot: Dartmouth Publishing.

Azar, E. and J. Burton. 1986. International conflict resolution: theory and practice. Brighton: Wheatsheaf. 
Baechler, G. and K.R. Spillman. 1996. Environmental degradation as a cause of war. Zurich: Ruegger.

Bakker, K. and G. Bridge. 2006. Material worlds? Resource geographies and the matter of nature. Progress in Human Geography 30(1): 5-27.

Bannon, I. and P. Collier. 2003. Natural resources and violent conflict: options and actions. Washington DC: the World Bank.

Barash, D.P. and C.P. Webel. 2017. Peace and conflict studies. Thousand Oaks: Sage Publications.

Bassett, T. J. 1988. The political ecology of peasant-herder conflicts in the northern Ivory Coast. Annals of the Association of American Geographers 78(3): 453-472.

Barquet, K., P. Lujala and J.K. Rød, 2014, Transboundary conservation and militarized interstate disputes. Political Geography 42: 1-11.

Bassett, T.J. and K.S. Zimmerer. 2004: Cultural ecology. In Gaile, G. and C. Willmott (eds.). Geography in America at the dawn of the twenty-first century. Oxford: Oxford University Press. Pp. 97-112.

Bebbington, A. and J. Bury (eds.). 2014. Subterranean struggles: new dynamics of mining, oil and gas in Latin America. Austin, TX: University of Texas Press.

Benjaminsen, T.A, K. Alinon, H. Buhaug and J.T. Buseth. 2012. Does climate change drive land-use conflicts in the Sahel? Journal of Peace Research 49: 97-111.

Bennett, J. 2009. Vibrant matter: a political ecology of things. Durham: Duke University Press.

Blaser, M. 2013. Caring for caribou/killing atîku: the common world and radical alterity. Social Justice Noted Scholars Lecture, University of British Columbia.

Blaikie, P.M. and H.C. Brookfield. 1987. Land degradation and society. London: Methuen.

Boelens, R. 2014. Cultural politics and the hydrosocial cycle: water, power and identity in the Andean highlands. Geoforum 57: 234-247.

Boelens, R., J. Hoogesteger, E. Swyngedouw, J. Vos and P. Wester. 2016. Hydrosocial territories: a political ecology perspective. Water International 41(1): 1-14.

Bohle, H.G. and H. Fünfgeld. 2007. The political ecology of violence in eastern Sri Lanka. Development and Change 38(4): 665-687.

Böhmelt, T., T. Bernauer, H. Buhaug, N.P. Gleditsch, T. Tribaldos, G. Wischnath. 2014. Demand, supply, and restraint: determinants of domestic water conflict and cooperation. Global Environmental Change 29: 337-348.

Bretthauer, J.M. 2015. Conditions for peace and conflict: applying a fuzzy-set qualitative comparative analysis to cases of resource scarcity. Journal of Conflict Resolution 59(4): 593-616.

Brock, A. and A. Dunlap. 2018. Normalising corporate counterinsurgency: engineering consent, managing resistance and greening destruction around the Hambach coal mine and beyond. Political Geography 62: 33-47.

Bryant, R.L. and S. Bailey. 1997. Third world political ecology. London: Routledge.

Buhaug H. 2010a. Dude, where's my conflict? LSG, relative strength, and the location of civil war. Conflict Management and Peace Science 27(2): 107-128.

Buhaug, H. 2010b. Climate not to blame for African civil wars. Proceedings of the National Academy of Sciences of the USA 107: 16477-16482.

Buhaug, H., J. Nordkvelle, T. Bernauer, T. Böhmelt, M. Brzoska, J.W. Busby, A. Ciccone, H. Fjelde, E. Gartzke, N.P. Gleditsch, J.A. Goldstone, H. Hegre, H. Holtermann, J.S.A. Link, P.M. Link, P. Lujala, J. O’Loughlin, C. Raleigh, J. Scheffran, J. Schilling, T.G. Smith, O.M. Theisen, R.S.J. Tol, H. Urdal and N. von Uexkull. 2014. One effect to rule them all? A comment on climate and conflict. Climatic Change 127(3-4): 391-397.

Buhaug, H., T.A. Benjaminsen, E. Sjaastad, and O.M. Theisen. 2015. Climate variability, food production shocks, and violent conflict in Sub-Saharan Africa. Environmental Research Letters 10(12): 125015.

Bullard, R.D. 1994. Unequal protection: environmental justice and communities of color. New York: Random House. 
Büscher, B. 2013. Transforming the frontier: peace parks and the politics of neoliberal conservation in Southern Africa. Durham: Duke University Press.

Büscher, B. 2010. Anti-politics as political strategy: neoliberalism and transfrontier conservation in Southern Africa. Development and Change 41(1): 29-51.

Büscher, B. and M. Ramutsindela. 2016. Green violence: Rhino poaching and the war to save Southern Africa's peace parks. African Affairs 115: 1-22.

Butler, C.K. and S. Gates. 2012. African range wars: climate, conflict, and property rights. Journal of Peace Research 49(1): 23-34.

Castree, N. 2002. False antitheses? Marxism, nature and actor-networks. Antipode 34(1): 111-146.

Cavanagh, C. and T.A. Benjaminsen. 2014. Virtual nature, violent accumulation: the 'spectacular failure' of carbon offsetting at a Ugandan National Park. Geoforum 56: 55-65.

Cochrane, F. 2008. Ending wars. Cambridge: Polity.

Cook, C. and K. Bakker. 2012. Water security: debating an emerging paradigm. Global Environmental Change 22(1): 94-102.

Collier, P. and A. Hoeffler. 2005. Resource rents, governance, and conflict. Journal of Conflict Resolution 49(4): 625-633.

Conca, K. and G.D. Dabelko. 2002. Environmental peacemaking. Washington DC: Woodrow Wilson Center Press and Baltimore, MA: Johns Hopkins University Press.

Conca, K. and J. Wallace. 2009. Environment and peacebuilding in war torn societies: lessons from the UN Environment Programme's experience with post conflict assessment. Global Governance 15(4): 485-504.

Conde, M. and P. Le Billon. 2017. Why do some communities resist mining projects while others do not? Extractive Industries and Society 4(3): 681-697.

Davis, D.K. 2007. Resurrecting the granary of Rome: environmental history and French colonial expansion in North Africa. Athens: Ohio University Press.

Duffy, R. 2006. Global governance and environmental management: the politics of transfrontier conservation areas in Southern Africa. Political Geography 25(1): 89-112.

Duffy, R. 2016. War, by conservation. Geoforum 69: 238-248.

EJOLT. 2013a. Environmental (in)justice. Background and definitions. http://www.ejolt.org/2013/02/environmental-injustice/

EJOLT. 2013b. Political ecology. http://www.ejolt.org/2013/02/political-ecology/

Escobar, A. 1998. Whose knowledge, whose nature? Biodiversity, conservation, and the political ecology of social movements. Journal of Political Ecology 5(1): 53-82.

Escobar, A. 2006. Difference and conflict in the struggle over natural resources: a political ecology framework. Development 49(3): 6-13.

Fairhead, J. and M. Leach. 1996. Misreading the African landscape: society and ecology in a forestsavanna mosaic. Cambridge: Cambridge University Press.

Fairhead, J., M. Leach and I. Scoones. 2012. Green grabbing: a new appropriation of nature? Journal of Peasant Studies 39(2): 237-261.

Floyd, R. and R. Matthew. 2013. Environmental security: approaches and issues. London: Routledge.

Folger, J.P., M.S. Poole and R.K. Stutman. 1996. Working through conflict. Boston: Addison Wesley Publishing Company.

Forsyth, T.J. 2008. Political ecology and the epistemology of social justice. Geoforum 39(2): 756-764.

Frerks, G., T. Dietz and P. van der Zaag. 2014. Conflict and cooperation on natural resources: justifying the CoCooN programme. In Bavinck M., L. Pellegrini and E. Mostert (eds.) Conflicts over natural resources in the global south-conceptual approaches. London: CRC Press. Pp. 13-34. 
Furlong, K., N.P. Gleditsch and H. Hegre. 2006. Geographic opportunity and neoMalthusian willingness: boundaries, shared rivers, and conflict. International Interactions 32(1): 79-108.

Galtung, J. 1969. Violence, peace, and peace research. Journal of Peace Research 6(3): 167-191.

Galtung, J. 1996. Peace by peaceful means: peace and conflict, development and civilization. Thousand Oaks: Sage.

Gjessing, G. 1967. Ecology and peace research. Journal of Peace Research 4(2): 125-138.

Gleditsch, N.P. 1998. Armed conflict and the environment: a critique of the literature. Journal of Peace Research 35(3): 381-401.

Gleditsch, N.P. 2012. Whither the weather? Climate change and conflict. Journal of Peace Research 49(1): 3-9.

Gleditsch, N.P. and O.M. Theisen. 2010. Resources, the environment and conflict. In M. Dunn Cavelty and V. Mauer (eds.) The Routledge handbook of security studies. London: Routledge. Pp. 221-232.

Gleditsch, N.P. and H. Urdal. 2002. Ecoviolence? Links between population growth, environmental scarcity and violent conflict in Thomas Homer-Dixon's work. Journal of International Affairs 56(1): 283-302.

Grech-Madin, C., S. Döring, K. Kim and A. Swain. 2018. Negotiating water across levels: a peace and conflict "toolbox" for water diplomacy. Journal of Hydrology 559: 100-109.

Greenberg, J. B. and T.K. Park. 1994. Political ecology. Journal of Political Ecology 1(1): 1-12.

Hartmann, B. 2001. Will the circle be unbroken? A critique of the project on environment, population, and security. In N.L. Peluso and M.J. Watts (eds.) Violent environments. Ithaca: Cornell University Press. Pp. 39-62.

Holifield, R. 2015. Environmental justice and political ecology. In T. Perreault, G. Bridge and J. McCarthy (eds.) Routledge handbook of political ecology. London: Routledge. Pp. 585-597.

Homer-Dixon, T.F. 1991. On the threshold: environmental changes as causes of acute conflict. International Security 16(2): 76-116.

Homer-Dixon, T.F. 1999. Environment, scarcity and violence. Princeton: Princeton University Press.

Horowitz, L.S. 2011. Interpreting industry's impacts: micropolitical ecologies of divergent community responses. Development and Change 42(6): 1379-1391.

Hsiang, S.M., M. Burke and E. Miguel. 2013. Quantifying the influence of climate on human conflict. Science 341(6151).

Hsiang, S.M., K.C. Meng and M.A Cane. 2011. Civil conflicts are associated with the global climate. Nature 476: 438-441.

Huber, M.T. 2017. Hidden abodes: industrializing political ecology. Annals of the American Association of Geographers 107(1): 151-166.

Ide, T. 2015. Why do conflicts over scarce renewable resources turn violent? A qualitative comparative analysis. Global Environmental Change 33: 61-70.

Ide, T. 2017. Research methods for exploring the links between climate change and conflict. WIRES Climate Change 8(3): 1-14.

Ide, T. 2018. Does environmental peacemaking between states work? Insights on cooperative environmental agreements and reconciliation in international rivalries. Journal of Peace Research 55: 351-365.

Ioris, A.A. 2015. Theorizing state-environment relationships: antinomies of flexibility and legitimacy. Progress in Human Geography 39(2): 167-184.

Kalyvas, S. 2006. The logic of violence in civil war. Cambridge: Cambridge University Press.

Jabri, V. 2013. Peacebuilding, the local and the international: a colonial or a postcolonial rationality? Peacebuilding 1: 3-16.

Jarosz, L. 2004. Political ecology as ethical practice. Political Geography 23(7): 917-927. 
Kelley, C., S. Mohtadi, M.A. Cane, R. Seager and Y. Kushnir. 2015. Climate change in the fertile crescent and the implications of the recent Syrian drought. Proceedings of the National Academy of Sciences 112 (11): 3241-3246.

Klare, M. 2012. The race for what's left: the global scramble for the world's last resources. London: Macmillan.

Koopman, S. 2011. Alter-geopolitics: other securities are happening. Geoforum 42(3): 274-284.

Korf, B. 2011. Resources, violence and the telluric geographies of small wars. Progress in Human Geography 35(6): 733-756.

Koubi, V., G. Spilker, T. Böhmelt and T. Bernauer. 2014. Do natural resources matter for interstate and intrastate armed conflict? Journal of Peace Research 51(2): 227-243.

Krampe, F. 2017. Towards a sustainable peace: a new research agenda for post-conflict natural resource management. Global Environmental Politics 14(4): 1-4.

Lahiri-Dutt, K. 2015. The silent (and gendered) violence. In Buechler, S. and A-M. Hanson (eds.) A political ecology of women, water and global environmental change. London: Routledge.

Latour, B. 2014. Agency at the time of the Anthropocene. New Literary History 45(1): 1-18.

Le Billon, P. 2008. Diamond wars? Conflict diamonds and geographies of resource wars. Annals of the Association of American Geographers 98(2): 345-372.

Le Billon, P. 2013. Wars of plunder: conflicts, profits and the politics of resources. Oxford: Oxford University Press.

Le Billon, P. and M. Sommerville. 2017. Landing capital and assembling 'investable land' in the extractive and agricultural sectors. Geoforum 82: 212-224.

Lederach, A.J. 2017. "The campesino was born for the campo": a multispecies approach to territorial peace in Colombia. American Anthropologist 119(4): 589-602.

Lederach, J.P. 2005. The moral imagination: the art and soul of building peace. Oxford: Oxford University Press.

Lesser, I.O. 1989. Resources and strategy. Berlin: Springer.

Li, F. 2013. Relating divergent worlds: mines, aquifers and sacred mountains in Peru. Anthropologica 55(2): 399-411.

Li, T.M. 2014. What is land? Assembling a resource for global investment. Transactions of the Institute of British Geographers 39(4): 589-602.

Libiszewski, S. 1991. What is an environmental conflict? Journal of Peace Research 28(4): 407-422.

Lombard, L. 2016. Threat economies and armed conservation in northeastern Central African Republic. Geoforum, 69: 218-226.

Lujala, P. 2010. The spoils of nature: armed civil conflict and rebel access to natural resources. Journal of Peace Research 47(1): 15-28.

Mann, G. 2009. Should political ecology be Marxist? A case for Gramsci's historical materialism. Geoforum 40(3): 335-344.

Marijnen, E. and J. Verweijen. 2016. Selling green militarization: the discursive (re)production of militarized conservation in the Virunga National Park, Democratic Republic of the Congo. Geoforum 75: 274-285.

Martinez-Alier J., L. Temper, D. Del Bene and A. Scheidel. 2016. Is there a global environmental justice movement? The Journal of Peasant Studies 43(3): 731-755.

Martinez-Alier, J. 2003. The environmentalism of the poor: a study of ecological conflicts and valuation. Cheltenham: Edward Elgar.

Martinez-Alier, J. 2009. Social metabolism, ecological distribution conflicts, and languages of valuation. Capitalism Nature Socialism 20(1): 58-87. 
Massé, F. and E. Lunstrum. 2016. Accumulation by securitization: commercial poaching, neoliberal conservation and the creation of new wildlife frontiers. Geoforum 69: 227-237.

Mehta, L. 2010. Limits to scarcity: contesting the politics of allocation. London: Earthscan.

Menga, F. 2017. Hydropolis: reinterpreting the polis in water politics. Political Geography 60: 100-109.

Moore, D.S. 1993. Contesting terrain in Zimbabwe's eastern highlands: political ecology, ethnography, and peasant resource struggles. Economic Geography 69(4): 380-401.

Neumann, R. 2014. Making political ecology. London: Routledge.

Nixon, R. 2011. Slow violence and the environmentalism of the poor. Cambridge, MA: Harvard University Press.

Østby, G., H. Urdal, M.Z. Tadjoeddin, S.M. Murshed and H. Strand. 2011. Population pressure, horizontal inequality and political violence: a disaggregated study of Indonesian provinces, 1990-2003. Journal of Development Studies 47(3): 377-398.

Patomäki, H. 2001. The challenge of critical theories: peace research at the start of the new century. Journal of Peace Research 38(6): 723-737.

Paulson, S., L.L. Gezon, and M.J. Watts. 2003. Locating the political in political ecology: an introduction. Human Organization 62(3): 205-217.

Pellow, D.N., A. Weinberg and A. Schnaiberg. 2001. The environmental justice movement: equitable allocation of the costs and benefits of environmental management outcomes. Social Justice Research 14(4): 423-439.

Peluso, N.L. 2002. Studying, writing, and telling violence in Indonesian forest environments. Paper presented at the Annual Meeting of the Association of American Geographers.

Peluso, N.L. and M.J. Watts (eds.). 2001. Violent environments. Ithaca: Cornell University Press.

Perreault, T. 2013. Dispossession by accumulation? Mining, water and the nature of enclosure on the Bolivian Altiplano. Antipode 45(5): 1050-1069.

Raleigh, C. and D. Kniveton. 2012, Come rain or shine: an analysis of conflict and climate variability in East Africa. Journal of Peace Research 49: 51-64.

Raleigh, C., A. Linkie and J. O. Loughlin. 2014. Extreme temperatures and violence. Nature Climate Change 4: 76-77.

Ramsbotham, O. 2005. The analysis of protracted social conflict: a tribute to Edward Azar. Review of International Studies 31: 109-126.

Ramsbotham, O., T. Woodhouse and H. Miall. 2016. Contemporary conflict resolution. $4^{\text {th }}$ Edition. Cambridge: Polity.

Ribot, J.C. and N.L. Peluso. 2003. A theory of access. Rural Sociology 68(2): 153-181.

Richardson, L.F. 1960. Statistics of deadly quarrels. Pacific Grove, CA: Boxwood Press.

Robbins, P. 2004/2012. Political ecology: a critical introduction. $2^{\text {nd }}$ ed. Oxford: Wiley.

Rocheleau, D.E. 1995. Maps, numbers, text, and context: mixing methods in feminist political ecology. The Professional Geographer 47(4): 458-466.

Rocheleau, D.E. 2008. Political ecology in the key of policy: from chains of explanation to webs of relation. Geoforum 39(2): 716-727.

Rogers, P. 2013. Peace studies. In A. Collins (ed.) Contemporary security studies. Oxford: Oxford University Press. Pp. 54-66.

Ross, M.L. 2015. What have we learned about the resource curse? Annual Review of Political Science 18: 239-259.

Salehyan, I. 2014. Climate change and conflict: making sense of disparate findings. Political Geography 43: 1-5. 
Schilling, J., S.L. Nash, T. Ide, J. Scheffran, R. Froese and P. von Prondzinski. 2017. Resilience and environmental security: towards joint application in peacebuilding. Global Change, Peace and Security 29(2): 107-127.

Slettebak, R.T. 2012. Don't blame the weather! Climate-related natural disasters and civil conflict. Journal of Peace Research 49: 163-176.

Schlosberg, D. 2007. Defining environmental justice: theories, movements, and nature. Oxford: Oxford University Press.

Schulz, K.A. 2017. Decolonizing political ecology: ontology, technology and 'critical' enchantment. Journal of Political Ecology 24: 125-143.

Selby, J. 2018. Climate change and the Syrian civil war, Part II: the Jazira's agrarian crisis. Geoforum. https://doi.org/10.1016/j.geoforum.2018.06.010

Selby, J. and C. Hoffmann. 2014. Rethinking climate change, conflict and security. Geopolitics 19: 747756.

Selby, J., O. Dahi, C. Fröhlich and M. Hulme. 2017a. Climate change and the Syrian civil war revisited. Political Geography 60: 251-252.

Selby, J., O. Dahi, C. Fröhlich and M. Hulme. 2017b. Climate change and the Syrian civil war revisited: a rejoinder. Political Geography 60: 253-255.

Sneddon, C., L. Harris, R. Dimitrov, and U. Özesmi. 2002. Contested waters: conflict, scale, and sustainability in aquatic socioecological systems. Society and Natural Resources 15(8): 663-675.

Sowers, J.L., E. Weinthal, and N. Zawahri. 2017. Targeting environmental infrastructures, international law, and civilians in the new Middle Eastern wars. Security Dialogue 48(5): 410-430.

Springer, S. and P. Le Billon. 2016. Violence and space: an introduction to the geographies of violence. Political Geography 52: 1-3.

Staddon, C. 2009. Towards a critical political ecology of human-forest interactions: collecting herbs and mushrooms in a Bulgarian locality. Transactions of the Institute of British Geographers 34(2): 161176.

Steinberg, J. 2018. Protecting the capital? On African geographies of protest escalation and repression. Political Geography 62: 12-22.

Sullivan, S. 2017. What's ontology got to do with it? On nature and knowledge in a political ecology of the 'green economy'. Journal of Political Ecology 24: 217-242.

Sultana, F. 2007. Reflexivity, positionality and participatory ethics: Negotiating fieldwork dilemmas in international research. ACME: An International Journal for Critical Geographies 6: 374-385.

Swyngedouw, E. 1999. Modernity and hybridity: nature, regeneracionismo, and the production of the Spanish waterscape, 1890-1930. Annals of the Association of American Geographers 89(3): 443465.

Taylor, M. 2014. The political ecology of climate change adaptation: livelihoods, agrarian change and the conflicts of development. London: Routledge.

Temper, L., D. del Bene and J. Martinez-Alier. 2015. Mapping the frontiers and front lines of global environmental justice: the EJAtlas. Journal of Political Ecology 22: 255-278.

To, P. X., S. Mahanty and W. Dressler. 2014. Social networks of corruption in the Vietnamese and Lao cross-border timber trade. Anthropological Forum 24(2): 154-174.

Tolia-Kelly, D.P. 2011. Narrating the postcolonial landscape: archaeologies of race at Hadrian's Wall. Transactions of the Institute of British Geographers 36(1): 71-88.

Tollefsen, A.F., H. Strand and H. Buhaug. 2012. PRIO-GRID: a unified spatial data structure. Journal of Peace Research 49(2): 363-374.

Tschakert, P. 2012. From impacts to embodied experiences: tracing political ecology in climate change research. Geografisk Tidsskrift-Danish Journal of Geography 112(2): 144-158. 
Turner, M.D. 2004. Political ecology and the moral dimensions of 'resource conflicts': the case of farmerherder conflicts in the Sahel. Political Geography 23(7): 863-889.

Turner, M.D. 2014. Political ecology I: an alliance with resilience? Progress in Human Geography 38(4): 616-623.

Turner, M.D. 2016. Political ecology II: engagements with ecology. Progress in Human Geography 40(3): 413-421.

Turner, M.D., A.A. Ayantunde, K.P. Patterson and E.D. Patterson. 2011. Livelihood transitions and the changing nature of farmer-herder conflict in Sahelian West Africa. Journal of Development Studies 47: 183-206.

Tyner, J. and J. Inwood. 2014. Violence as fetish geography, Marxism, and dialectics. Progress in Human Geography 38(6): 771-784.

Unruh, J.D. 2003. Land tenure and legal pluralism in the peace process. Peace and Change 28(3): 352-377.

Velicu, I. and M. Kaika. 2017. Undoing environmental justice: re-imagining equality in the Rosia Montana anti-mining movement. Geoforum 84: 305-315.

Walker, P.A. 2005. Political ecology: where is the ecology? Progress in Human Geography 29(1): 73-82.

Watts, M.J. 1983. Hazards and crises: a political economy of drought and famine in Northern Nigeria. Antipode 15(1): 24-34.

Watts, M.J. 1983. Silent violence: food, famine, and peasantry in northern Nigeria. Berkeley, CA: University of California Press.

Watts, M.J. 2004. Resource curse? Governmentality, oil and power in the Niger Delta, Nigeria. Geopolitics 9(1): 50-80.

Watts, M.J. and R. Peet. 2004. Liberating political ecology. In Peet, R. and M.J. Watts (eds.) Liberation ecologies: environment, development, social movements. London: Routledge. Pp. 3-43.

Webel, C. and J. Galtung. (eds.). 2007. Handbook of peace and conflict studies. London: Routledge.

Wolf, E.R. 1972. Ownership and political ecology. Anthropological Quarterly 45(3): 201-205.

Wolford, W. 2004. This land is ours now: spatial imaginaries and the struggle for land in Brazil. Annals of the Association of American Geographers 94(2): 409-424.

Yates, J.S., L.M. Harris and N.J. Wilson. 2017. Multiple ontologies of water: politics, conflict and implications for governance. Environment and Planning D: Society and Space 35(5): 797-815.

Ybarra, M. 2016. 'Blind Passes' and the production of green security through violence on the Guatemalan border. Geoforum 69: 194-206.

Zalik, A. 2011. Protest-as-violence in oil fields: the contested representation of protests in two extractive sites. In S. Feldman, C. Geisler and G.A. Menon (eds.). Accumulating insecurity: violence and dispossession in the making of everyday life. Athens: University of Georgia Press. Pp. 261-284.

Zeitoun, M. and J. Warner. 2006. Hydro-hegemony-a framework for analysis of trans-boundary water conflicts. Water Policy 8(5): 435-460.

Zeitoun, M., A.E. Cascão, J. Warner, N. Mirumachi, N. Matthews, F. Menga, and R. Farnum. 2017. Transboundary water interaction III: contest and compliance. International Environmental Agreements: Politics, Law and Economics 17(2): 271-294.

Zhang, D.D., H.F. Lee, C. Wang, B. Li, Q. Pei, J. Zhang and Y. An. 2011. The causality analysis of climate change and large-scale human crisis. Proceedings of the National Academy of Sciences 108(42): 17296-17301.

Zografos C., M.C. Goulden, and G. Kallis. 2014. Sources of human insecurity in the face of hydro-climatic change. Global Environmental Change 29: 327-336. 